\title{
Extended half-life target module for sustainable UniCAR T-cell treatment of STn- expressing cancers
}

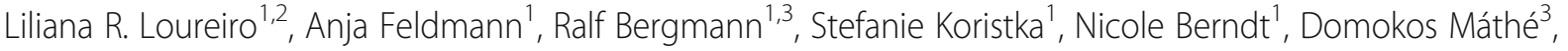 \\ Nikolett Hegedüs ${ }^{3}$, Krisztián Szigeti ${ }^{3}$, Paula A. Videira ${ }^{4}$, Michael Bachmann ${ }^{1,2,5,6^{*}}$ and Claudia Arndt ${ }^{1}$
}

\begin{abstract}
Background: Adapter chimeric antigen receptor (CAR) approaches have emerged has promising strategies to increase clinical safety of CAR T-cell therapy. In the UniCAR system, the safety switch is controlled via a target module (TM) which is characterized by a small-size and short half-life. The rapid clearance of these TMs from the blood allows a quick steering and self-limiting safety switch of UniCAR T-cells by TM dosing. This is mainly important during onset of therapy when tumor burden and the risk for severe side effects are high. For long-term UniCAR therapy, the continuous infusion of TMs may not be an optimal setting for the patients. Thus, in later stages of treatment, single infusions of TMs with an increased half-life might play an important role in long-term surveillance and eradication of residual tumor cells. Given this, we aimed to develop and characterize a novel TM with extended half-life targeting the tumor-associated carbohydrate sialyl-Tn (STn).

Methods: The extended half-life TM is composed of the STn-specific single-chain variable fragment (scFv) and the UniCAR epitope, fused to the hinge region and Fc domain of a human immunoglobulin 4 (IgG4) antibody. Specific binding and functionality of the aSTn-lgG4 TM as well as pharmacokinetic features were assessed using in vitro and in vivo assays and compared to the already established small-sized aSTn TM.

Results: The novel aSTn-lgG4 TM efficiently activates and redirects UniCAR T-cells to STn-expressing tumors in a target-specific and TM-dependent manner, thereby promoting the secretion of proinflammatory cytokines and tumor cell lysis in vitro and in experimental mice. Moreover, PET-imaging results demonstrate the specific enrichment of the aSTn-lgG4 TM at the tumor site, while presenting a prolonged serum half-life compared to the short-lived aSTn TM.

Conclusion: In a clinical setting, the combination of TMs with different formats and pharmacokinetics may represent a promising strategy for retargeting of UniCAR T-cells in a flexible, individualized and safe manner at particular stages of therapy. Furthermore, as these molecules can be used for in vivo imaging, they pose as attractive candidates for theranostic approaches.
\end{abstract}

Keywords: Immunotherapy, UniCAR T-cells, IgG4-based TM, Sialyl-Tn (STn)

\footnotetext{
* Correspondence: m.bachmann@hzdr.de

${ }^{1}$ Helmholtz-Zentrum Dresden-Rossendorf (HZDR), Institute of

Radiopharmaceutical Cancer Research, Bautzner Landstrasse 400, 01328

Dresden, Germany

${ }^{2}$ National Center for Tumor Diseases (NCT), Dresden, Germany; German Cancer Research Center (DKFZ), Heidelberg, Germany; Faculty of Medicine and

University Hospital Carl Gustav Carus, Technische Universität Dresden, Dresden, Germany; Helmholtz-Zentrum Dresden-Rossendorf (HZDR), Dresden, Germany

Full list of author information is available at the end of the article
}

(c) The Author(s). 2020 Open Access This article is licensed under a Creative Commons Attribution 4.0 International License, which permits use, sharing, adaptation, distribution and reproduction in any medium or format, as long as you give appropriate credit to the original author(s) and the source, provide a link to the Creative Commons licence, and indicate if changes were made. The images or other third party material in this article are included in the article's Creative Commons licence, unless indicated otherwise in a credit line to the material. If material is not included in the article's Creative Commons licence and your intended use is not permitted by statutory regulation or exceeds the permitted use, you will need to obtain permission directly from the copyright holder. To view a copy of this licence, visit http://creativecommons.org/licenses/by/4.0/ The Creative Commons Public Domain Dedication waiver (http://creativecommons.org/publicdomain/zero/1.0/) applies to the data made available in this article, unless otherwise stated in a credit line to the data. 


\section{Background}

CAR T-cell therapies are moving at a breakneck pace, demonstrating remarkable clinical success particularly in the treatment of blood malignancies [1]. Nevertheless, some challenges still hinder their broad clinical application, mainly related to on-target/off-tumor toxicity, cytokine release syndrome and tumor escape variants [2-5]. Several approaches have been pursued in recent years, aiming an increased safety by reducing the risk for these recurrently reported side effects. Among them, the UniCAR system developed by our group may fulfill the requirements to improve specificity and safety of CAR Tcell therapies [6]. In contrast to conventional CAR Tcell approaches, UniCAR T-cells are not directed to a tumor antigen but alternatively recognize the peptide epitope E5B9. This epitope is derived from the nuclear protein $\mathrm{La} / \mathrm{SS}-\mathrm{B}$, which is not accessible on the surface of intact living cells. UniCAR T-cells are therefore engineered to express universal receptors composed of the extracellular binding domain against the epitope E5B9, the transmembrane domain derived from CD28 as well as the intracellular signaling domains of CD28 and

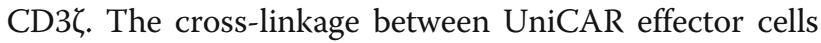
and target cells is mediated via a target module (TM) composed of a binding moiety against a specific tumor antigen fused to the E5B9 epitope (Fig. 1a) [7, 8]. This in turn leads to the specific activation of the otherwise inert UniCAR T-cells and allows a controlled on/off switch of the UniCAR T-cells in case severe side effects are observed. Furthermore, multiple targeting strategies can be considered given that TMs can be easily constructed and interchanged using different formats and specificities [8-12].

A repertoire of small-sized TMs directed against various tumor-associated antigens has been developed in our group. Given their short half-life, these TMs are rapidly eliminated from the blood [8-12], which allows a quick control over UniCAR T-cell activity in case side effects occur. Nonetheless, continuous administration is required during therapy to maintain effective TM concentrations and perpetuate tumor cell killing by UniCAR T-cells. Considering long-term treatment, a prolonged activation of UniCAR T-cells to eradicate residual tumor cells as well as reduction of TM infusions may be desirable for an improved therapeutic approach and patient care at later phases of therapy. Therefore, in this work we aimed to establish an extended half-life TM that could present a promising tool for late-stage UniCAR Tcell therapy while preserving the switchable safety features of the UniCAR system. Within the collection of small-sized TMs developed, a scFv-based TM directed against the tumor-associated carbohydrate antigen sialyl$\mathrm{Tn}(\mathrm{STn})$ was proven to efficiently and specifically redirect UniCAR T-cells to STn-expressing cancer cells [12].

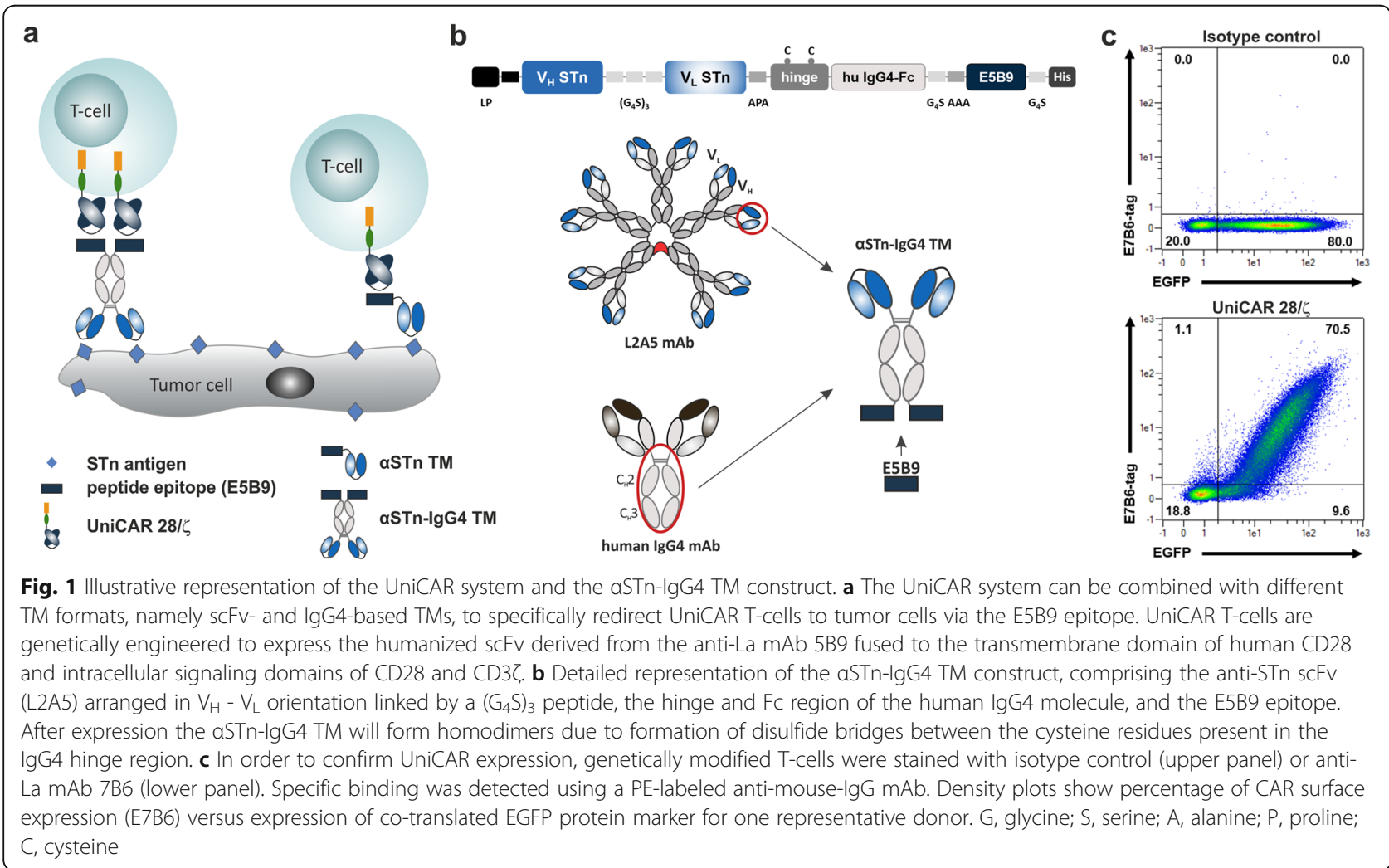


This antigen is widely overexpressed in several types of human carcinomas, such as gastric [13], colorectal [14], ovarian [15], breast [16] and bladder [17] carcinomas. Given that STn expression modulates a malignant phenotype and is particularly associated with cancer aggressiveness, metastasis and poor prognosis [18-20], increasing attention has been recently drawn towards this tumor antigen. Building upon this TM, a novel $\alpha \mathrm{STn}$ IgG4 TM based on the Fc region of immunoglobulin 4 (IgG4) antibodies was developed and assessed for its capability to redirect UniCAR T-cells to STn-expressing cancer cells both in vitro and in vivo.

\section{Methods}

\section{Cell lines}

STn expression is absent in the wild-type (WT) human bladder cancer cell line MCR and in the WT human breast cancer cell line MDA-MB-231 when cultured in vitro. Therefore, MCR and MDA-MB-231 cell lines expressing the STn antigen were generated as previously reported [17, 21]. The murine 3T3 (ATCC CRL-1658) fibroblast cells were used for production of $\alpha \mathrm{STn}$ and aSTn-IgG4 TMs. Human embryonic kidney cells HEK293T (ATCC CRL-11268) served as virus producing cells. The MDA-MB-231 STn ${ }^{+}$cell line was additionally transduced with an open reading frame encoding the firefly luciferase as previously described [22] and termed MDA-MB-231 STn ${ }^{+}$Luc. All cell lines were cultured in Dulbecco's modified Eagle medium (DMEM), supplemented with $10 \%(\mathrm{v} / \mathrm{v})$ FBS, $2 \mathrm{mM}$ L-glutamine, $100 \mathrm{U} /$ $\mathrm{ml}$ of penicillin and $100 \mu \mathrm{g} / \mathrm{ml}$ of streptomycin (Biochrom) and maintained at $37^{\circ} \mathrm{C}$ in a humidified atmosphere of $5 \% \mathrm{CO}_{2}$. For routine cell culture and in preparation for experiments, cells were harvested from the culture flasks using Trypsin-EDTA diluted in sterile phosphate-buffered saline (PBS).

\section{Construction, expression and purification of recombinant antibodies}

The $\alpha \mathrm{STn}$ TM was produced as described previously [12]. For in silico construction of the $\alpha S T n-I g G 4 T M$, the variable light $\left(\mathrm{V}_{\mathrm{L}}\right)$ and heavy $\left(\mathrm{V}_{\mathrm{H}}\right)$ chains of the monoclonal antibody (mAb) L2A5 were arranged in a $\mathrm{V}_{\mathrm{H}}-\mathrm{V}_{\mathrm{L}}$ orientation and connected by a $\left(\mathrm{Gly}_{4} \mathrm{Ser}\right)_{3}$ linker. The variable regions were further linked downstream to the hinge and $\mathrm{Fc}$ region $\left(\mathrm{C}_{\mathrm{H}} 2-\mathrm{C}_{\mathrm{H}} 3\right)$ derived from a human IgG4 antibody. The UniCAR tag (E5B9) followed by a $6 \mathrm{xHis}$ tag was fused to the C-terminus of this molecule. An Igk leader peptide (LP) sequence was fused to the $\mathrm{N}$-terminus to promote secretion of the TM into the cell culture supernatant. The final sequence was cloned into the vector p6NST50 and used for generation of stable TM-producing 3T3 cell lines. Recombinant TMs were purified from cell culture supernatant via protein A affinity chromatography according to manufacturer's instructions (Protein A HP Spin Trap, Sigma-Aldrich) followed by overnight dialysis in PBS (Biochrom). Finally, SDS-PAGE and immunoblotting were used to assess potential contaminants and to determine protein concentration as previously described $[23,24]$.

\section{Isolation, maintenance and lentiviral transduction of human T-cells with UniCAR vectors}

Primary human T-cells were isolated from peripheral blood mononuclear cells (PBMCs) of buffy coats (supplied by German Red Cross, Dresden, Germany), transduced with UniCAR vectors, sorted and cultured as described previously [23]. Cloning of UniCAR vectors and production of UniCAR T-cells have been also described before [23, 25]. UniCAR vectors include the signaling UniCAR CD28/ $\zeta$ construct, which contains the co-stimulatory $\mathrm{CD} 28$ and activating $\mathrm{CD} 3 \zeta$ domains; the UniCAR Stop construct that lacks any intracellular signaling domains; and the UniCAR vector control, encoding only for the EGFP marker protein.

\section{High-performance liquid chromatography}

Purity of the purified TMs was assessed using size exclusion high-performance liquid chromatography (SE-HPLC) as described by Albert et al [10].

\section{Flow-cytometry analysis}

Specific binding of $\alpha \mathrm{STn}$ or $\alpha \mathrm{STn}$-IgG4 TM to STnexpressing cancer cells and respective equilibrium dissociation constant $\left(K_{\mathrm{D}}\right)$ values were determined using flow cytometry. Shortly, $3 \times 10^{5} \mathrm{STn}^{+}$or WT $\left(\mathrm{STn}^{-}\right)$cancer cells were incubated for $1 \mathrm{~h}$ with $10 \mathrm{ng} / \mu \mathrm{l}$ or increasing concentrations of TM, followed by a washing step and subsequent incubation with mouse anti-La (5B9) $\mathrm{mAb}$ for $30 \mathrm{~min}$. Signal was detected using the PEconjugated goat anti-mouse IgG mAb (Beckmann Coulter) after $30 \mathrm{~min}$ of incubation. In order to verify UniCAR expression on the surface of T-cells, the primary anti-La mAb 7B6 and secondary PE-labeled goat anti-mouse-IgG mAb (Beckmann Coulter) were used as described previously [25]. All incubation steps were performed at $4{ }^{\circ} \mathrm{C}$ in the dark. Stained cells were analyzed using a MACSQuant Analyzer and MACSQuantify software (Miltenyi Biotec). Based on the relative median fluorescence intensity (MFI) of stained cells, a binding curve was obtained and $K_{\mathrm{D}}$ values were calculated using the nonlinear regression curve fit (95\% confidence interval) with GraphPad Prism 7 software (GraphPad Software Inc.).

\section{Cytokine-release assay}

To determine the levels of secreted cytokines, cell-free supernatants from the co-culture of target cells and 
UniCAR T-cells in the presence or absence of TM were harvest after $24 \mathrm{~h}$ incubation. Cytokine concentrations were quantified using the MACSPlex Cytokine $12 \mathrm{Kit}$ (Miltenyi Biotec) according to the manufacturer's instructions.

\section{Cell-mediated cytotoxicity assay}

Cancer cell lysis mediated by UniCAR T-cells was assessed in vitro by standard chromium-release assay [26]. Briefly, ${ }^{51} \mathrm{Cr}$-labeled $\mathrm{STn}^{+}$cancer cells were cocultured with the genetically modified UniCAR T-cells in the presence or absence of TMs for $24 \mathrm{~h}$. An effector to target cell (E:T) ratio of 5:1 was used. Different concentrations of TM were applied to calculate the half maximal effective concentration $\left(\mathrm{EC}_{50}\right)$ value.

\section{TM radiolabeling}

All solvents were purchased from commercial sources (Sigma-Aldrich, Fluka, VWR, Fisher Scientific). The no carrier added $(\mathrm{NCA})\left[{ }^{64} \mathrm{Cu}\right] \mathrm{Cu}^{2+}$ was produced at the Helmholtz-Zentrum Dresden-Rossendorf on a TR-Flex (Advanced Cyclotron Systems Inc.) by ${ }^{64} \mathrm{Ni}(\mathrm{p}, \mathrm{n}){ }^{64} \mathrm{Cu} \mathrm{nu}-$ clear reaction and prepared as reported previously [27]. For labeling of the $\alpha \mathrm{STn}$ and $\alpha \mathrm{STn}$-IgG4 TMs with ${ }^{64} \mathrm{Cu}, \quad\left[{ }^{64} \mathrm{Cu}\right] \mathrm{CuCl}_{2} \quad(200 \mathrm{MBq}$ in $0.01 \mathrm{M} \mathrm{HCl}, 0.3 \mathrm{M}$ $\mathrm{NH}_{4} \mathrm{OAc}, \mathrm{pH} 5.0$ ) was added to $9.2 \pm 6.7 \mathrm{nmol}$ of the TMs and tempered at $38{ }^{\circ} \mathrm{C}$ for $30 \mathrm{~min}$. Labeling yield and radiochemical purity were determined using radio thin-layer chromatography (radio-ITLC). The radioITLC was carried out on SG stripes (Merck) using $0.1 \mathrm{M}$ citrate, $0.01 \mathrm{M}$ EDTA. The developed chromatograms were analyzed by autoradiography using the In-vivo Multispectral Imaging System (Bruker).

\section{In vivo experiments using NOD-SCID mice and bioluminescence imaging}

Non-obese diabetic (NOD)-severe combined immunedeficient (SCID) female mice at 6 weeks of age were purchased from Janvier Labs (NOD.CB17-Prkd $c^{\text {scid } / R j) . ~ A l l ~}$ mice used throughout these experiments were healthy and not involved in previous procedures. Health status of mice was monitored daily by husbandry staff. Mice were euthanized during experiment if they showed hunched abnormal posture, impaired mobility, rough coat, or paralysis. At the end of all experiments, animals were euthanized using carbon dioxide inhalation and cervical dislocation. All animal procedures were approved by the university committee for animal welfare.

To assess in vivo functionality of $\alpha \mathrm{STn}$ and $\alpha \mathrm{STn}$ IgG4 TMs, optical imaging analysis was performed in which $0.5 \times 10^{6}$ UniCAR T-cells were mixed with $1 \times 10^{6}$ MDA-MB-231 STn ${ }^{+}$Luc cells in the presence or absence of $300 \mathrm{pmol}$ of $\alpha \mathrm{STn}$ or $\alpha \mathrm{STn}$-IgG4 TM. The corresponding mixtures were subcutaneously injected in the right flank of NOD-SCID mice. Mice were anesthetized using 10\% (v/v) desflurane (Baxter) and maintained with $8 \%(\mathrm{v} / \mathrm{v})$ desflurane inhalation in $30 \%(\mathrm{v} / \mathrm{v})$ oxygen in order to perform luminescence imaging. Subsequently, mice were injected intraperitoneally with $200 \mu \mathrm{L}$ of Dluciferin in PBS at a final concentration of $15 \mathrm{mg} / \mathrm{ml}$ (Thermo Fisher Scientific). X-ray and luminescence images were acquired 5-10 min after luciferin injection. Bioluminescence imaging was performed at day 0,1 and 3 using In-vivo Multispectral Imaging System (Bruker). Images were analyzed using the MI 5.3 and MS 1.3 software (Bruker). Quantitative analysis was performed assessing net luminescence intensities of the tumors (photons $/ \mathrm{s} / \mathrm{mm}^{2}$ ).

\section{Positron emission tomography (PET) imaging of tumor xenograft models}

PET imaging was performed to assess pharmacokinetics and specific accumulation of radiolabeled $\alpha S T n$ TMs $\left(\left[{ }^{64} \mathrm{Cu}\right] \mathrm{Cu}-\mathrm{NODAGA}-\alpha \mathrm{STn}\right.$ and $\left[{ }^{64} \mathrm{Cu}\right] \mathrm{Cu}-\mathrm{NODAGA}-$ $\alpha \mathrm{STn}$-IgG4 TM) at the tumor site. Tumor induction was achieved by subcutaneous injection of a suspension containing $2 \times 10^{6}$ MDA-MB-231 STn ${ }^{+}$Luc cells in PBS into the right shoulder of the mice. Mice were kept under the above-mentioned conditions for 2 to 3 weeks to allow tumor growth. Thereafter, MDA-MB-231 STn ${ }^{+}$ Luc tumor-bearing mice were anesthetized as previously described and $0.7 \mathrm{nmol}$ of $\left[{ }^{64} \mathrm{Cu}\right] \mathrm{Cu}-\mathrm{NODAGA}-\alpha \mathrm{STn}$ or $\left[{ }^{64} \mathrm{Cu}\right] \mathrm{Cu}-\mathrm{NODAGA}-\alpha \mathrm{STn}$-IgG4 TM were intravenously injected into a lateral tail vein of the mice. Imaging was performed using dynamic scans acquired over $2 \mathrm{~h}$ with a small animal PET scanner (microPET P4, Siemens) at time point $0 \mathrm{~h}$, and over $1 \mathrm{~h}$ at the time points $7,20,47$ and $66 \mathrm{~h}$ after TM injection. Standard uptake values (SUV) defined as tissue concentration $(\mathrm{MBq} / \mathrm{mL}) /$ injected dose $(\mathrm{MBq}) /$ body weight $(\mathrm{g})$ in $(\mathrm{g} / \mathrm{ml})$ were used to express activity concentrations. Images were visualized and quantified using ROVER software (ABX).

\section{Statistical analysis}

Statistical significance was determined using GraphPad Prism software 7.0 (GraphPad Software Inc.). Statistical tests were specified in the respective figure legends. $P$ values below 0.05 were considered significant as follows: $" p<0.1 ; * * p<0.01 ; * * * p<0.001$ and ${ }^{* * * * * *} p<0.0001$. All error bars are represented either as standard error of the mean (SEM) or standard deviation (SD).

\section{Results}

Construction of a novel IgG4-based TM targeting the STn antigen

As previously described, UniCAR T-cells have been successfully redirected using TMs with different formats, such as nanobody- and scFv-based TMs, to target 
several tumor antigens [8-11]. In this work the possibility of producing and using a TM with increased size to redirect UniCAR T-cells was explored. Hence, a novel IgG4-based TM format targeting STn was constructed (Fig. 1). The structure of this construct is similar to the scFv-based TM with the additional insertion of the hinge and $\mathrm{Fc}_{\mathrm{C}}\left(\mathrm{C}_{\mathrm{H}} 2-\mathrm{C}_{\mathrm{H}} 3\right)$ regions derived from human IgG4 antibodies. These regions were introduced between the binding domain ( $\mathrm{scFv}$ ) derived from the $\alpha \mathrm{STn}$ mAb L2A5 [28] at the Nterminus, and the E5B9 epitope used for UniCAR Tcell recognition (Fig. 1b). A LP sequence was added $\mathrm{N}$-terminally to promote secretion of the TM into the cell culture supernatant and a His-tag was fused at the $\mathrm{C}$-terminus to allow TM detection. The entire sequence encodes one polypeptide chain and given that the cysteine residues present in the hinge region will form disulfide bridges, a secreted homodimer composed of two identical polypeptide chains is produced. This molecule resembles the format of an IgG4 antibody and has a molecular weight (MW) of around $111 \mathrm{kDa}$, which is considerably increased compared to a scFv-based TM $(35 \mathrm{kDa})$. Additionally, and based on the peptide tag E7B6 incorporated in the extracellular part of the UniCAR, cell surface expression on Tcells is routinely verified prior to performing the assays, as exemplified in Fig. 1c. Noteworthy, UniCAR expression directly correlates with the expression of co-translated EGFP marker protein.

\section{Expression, purification and characterization of the aSTn-} IgG4 TM

The open reading frame of the $\alpha \mathrm{STn}$-IgG4 TM was cloned into the p6NST50 vector which was used for transduction of murine 3T3 cells. The resulting cell line served for production of the TM. Purification from cell culture supernatants was performed using protein A affinity chromatography. The purified $\alpha$ STn-IgG4 TM was analyzed by SDS-PAGE, immunoblotting and size exclusion HPLC to confirm the correct molecular weight and purity. Given that the purified STn-IgG4 TM forms a homodimer, a MW of $111 \mathrm{kDa}$ is calculated for this molecule. However, due to the denaturing conditions of the SDS-PAGE, the disulfide bridges within the hinge region are reduced and $\alpha \mathrm{STn}$-IgG4 monomers are expected to be observed with a theoretical MW of $55 \mathrm{kDa}$. As shown in both the SDS-PAGE and WB analyses, a major band with a $\mathrm{MW}$ of around $60 \mathrm{kDa}$ corresponding to the $\alpha$ STn-IgG4 monomers is observed (Fig. 2a and b). Moreover, a faint band with a MW of around $130 \mathrm{kDa}$ was obtained, most likely representing the homodimeric conformation of the $\alpha \mathrm{STn}$-IgG4 TM. Size exclusion HPLC was used to further confirm the purity and size of the TM under native conditions. As expected, a major peak with $89 \%$ of the total area was observed with a MW of $143 \mathrm{kDa}$, corresponding to the homodimer $\alpha$ STn-IgG4 TM (Fig. 2c). Additionally, a minor peak (11\% of the total area) was obtained at a MW of 254 $\mathrm{kDa}$, which suggests the presence of $\alpha \mathrm{STn}$-IgG4

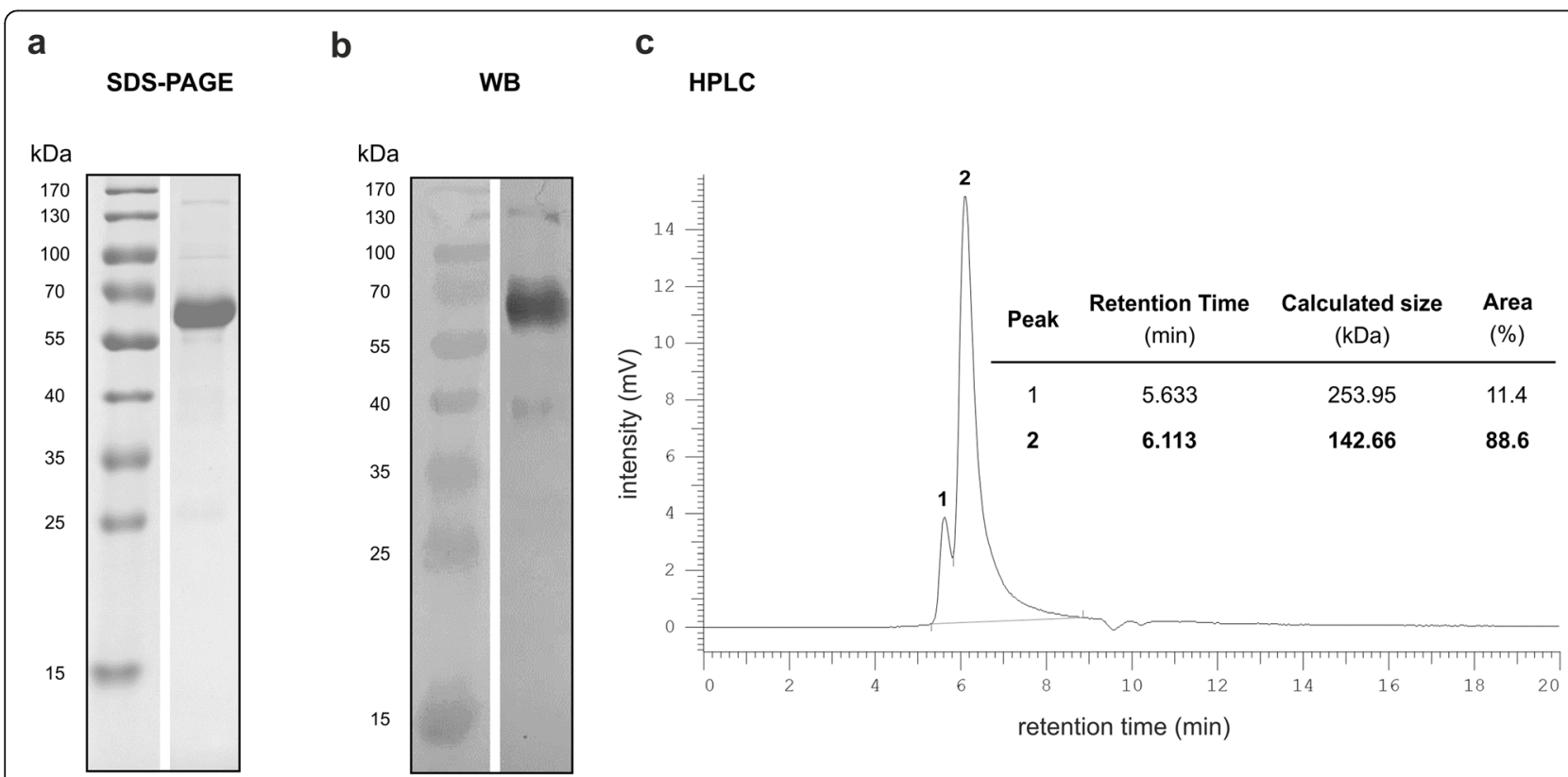

Fig. 2 Analysis of purified aSTn-lgG4 TM by SDS-PAGE, Western Blot and size exclusion HPLC. The aSTn-lgG4 TM was purified from the supernatant of TM-producing $3 T 3$ cells using protein A columns. The dialyzed TM was resolved by SDS-PAGE and stained with (a) Coomassie Brilliant Blue G250 or (b) analyzed by WB using aHis mAb for detection of the C-terminus His-tag. c Chromatogram obtained by size exclusion HPLC of $10 \mu \mathrm{g}$ of purified TM 
oligomers or possible contaminants (Fig. 2c). Collectively, these results demonstrate the successful production and purification of the homodimeric $\alpha \mathrm{STn}$-IgG4 TM with high purity for further in vitro and in vivo functional characterization.

\section{Binding and affinity assessment of the aSTn-lgG4 TM}

The first feature assessed was the capacity of the novel $\alpha \mathrm{STn}$-IgG4 TM to specifically bind to STn-expressing cancer cells. This was done by flow cytometry using the breast cancer cell line MDA-MB-231 STn ${ }^{+}$and the bladder carcinoma cell line MCR $\mathrm{STn}^{+}$. The parental antibody L2A $5 \mathrm{mAb}$ and the scFv-based TM $(\alpha \mathrm{STn}$ TM) were used as positive controls. As represented in Fig. 3a, $\alpha$ STn-IgG4 TM has a comparable binding pattern to both positive controls. Additionally, no binding was observed when performing an equivalent staining on the corresponding cancer cell lines lacking the expression of STn (WT cell lines) (Fig. S1). Binding affinity curves of both $\alpha$ STn TMs were obtained for STn-expressing cell lines by TM titration (Fig. 3b and c). Affinity binding values ( $K_{\mathrm{D}}$ values) of around $4 \mathrm{nM}$ were obtained for the $\alpha$ STn-IgG4 TM, in contrast to 57 and $75 \mathrm{nM}$ determined for the $\alpha \mathrm{STn}$ TM. This observation further corroborates the principle that more binding valences increase the binding strength of antibody derivatives. As the $\alpha \mathrm{STn}$ IgG4 TM has two $\alpha$ STn binding arms in comparison to the monovalent $\alpha \mathrm{STn} \mathrm{TM}$, it binds more effectively to STn-expressing tumor cells. The acquired data additionally show that after binding of the TM to the target antigen, the UniCAR tag (E5B9 epitope) is still accessible for recognition by the $\alpha E 5 B 9$ UniCAR domain, which is an important requirement for successful interaction with UniCAR T-cells. Overall, these results demonstrate that the $\alpha \mathrm{STn}$-IgG4 TM is able to specifically bind its target antigen on the surface of different cancer cell lines with an increased binding affinity in comparison to the previously designed $\alpha \mathrm{STn}$ TM.

\section{Engagement via aSTn-IgG4 TM leads to specific lysis of $\mathrm{STn}^{+}$tumor cells by UniCAR T-cells}

After confirming the specific binding of the $\alpha \mathrm{STn}$-IgG4 TM to STn-expressing cancer cells, functionality regarding in vitro killing efficiency was assessed using chromium release assays. For that, human T-cells from healthy donors were transduced with lentiviral vectors encoding either the UniCAR sequence comprising an intracellular signaling domain (UniCAR 28/ל), the UniCAR sequence lacking any signaling domains (UniCAR Stop) or the EGFP marker protein alone (vector control).

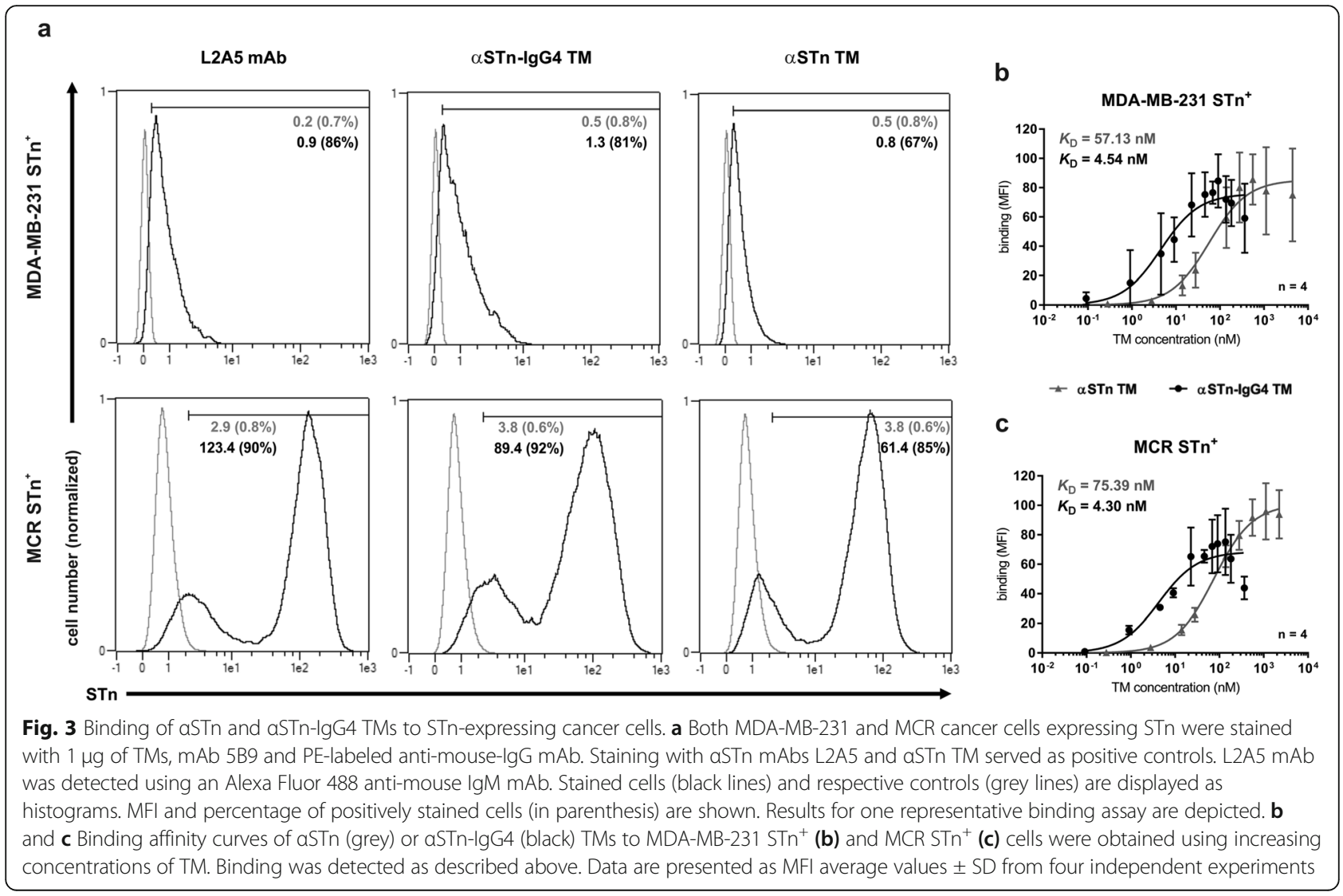


UniCAR Stop and vector control T-cells served as negative controls. Chromium release was measured $24 \mathrm{~h}$ after co-culture of STn-expressing cancer cells with transduced T-cells at an E:T ratio of 5:1 in the presence or absence of $\alpha$ STn-IgG4 TM or $\alpha$ STn TM. As shown in Fig. 4a and b, both TMs induce efficient lysis of STn-

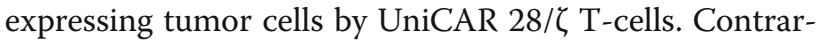
ily, UniCAR T-cells were not able to eradicate tumor cells in the absence of TM. As expected, UniCAR Stop and vector control $\mathrm{T}$-cells were completely inert in the presence or absence of TM. Using a similar assay set up, the $\alpha \mathrm{STn}$-IgG4 TM was titrated in order to calculate the $\mathrm{EC}_{50}$. As represented in Fig. $4 \mathrm{c}$ and d, $\mathrm{EC}_{50}$ values of 0.4 $\mathrm{nM}$ and $0.1 \mathrm{nM}$ were determined for MDA-MB-231 $\mathrm{STn}^{+}$and MCR STn ${ }^{+}$cells using the $\alpha \mathrm{STn}$-IgG4 TM, respectively. In comparison to the $\alpha \mathrm{STn} \mathrm{TM}(12.2 \mathrm{nM}$ and $25.0 \mathrm{nM}$ ), a lower concentration of $\alpha \mathrm{STn}$-IgG4 TM was sufficient to achieve a similar maximal tumor cell lysis. Most likely, the increased avidity results in higher killing efficiency of the $\alpha \mathrm{STn}$-IgG4 TM. Taken together, these data show that UniCAR T-cells can be redirected using an IgG4-based TM to specifically target STn-expressing cancer cells with increased efficiency.
UniCAR T-cells redirected by the aSTn-IgG4 TM promote the release of proinflammatory cytokines

Having substantiated the TM-mediated killing capacity of UniCAR T-cells upon cross-linkage to STnexpressing tumor cells using the $\alpha \mathrm{STn}$-IgG4 TM, the cytokine release pattern of UniCAR T-cells was assessed. For that, UniCAR T-cells were incubated in the presence or absence of MDA-MB-231 $\mathrm{STn}^{+}$(Fig. 5a) or MCR $\mathrm{STn}^{+}$(Fig. 5b) cells, with or without the $\alpha \mathrm{STn}$ or $\alpha \mathrm{STn}$ IgG4 TMs. After $24 \mathrm{~h}$ of incubation, the concentration of cytokines present in cell-free culture supernatants was analyzed using a multiplex assay (MACSPlex Cytokine $12 \mathrm{Kit})$. In this assay, detection and quantification of the cytokines TNF- $\alpha$, IFN- $\gamma$, IFN- $\alpha$, GM-CSF, IL- 2 , IL-4, IL5, IL-6, IL-9, IL-10, IL-12 and IL-17A are performed simultaneously. Significant cytokine concentrations were detected for TNF- $\alpha$, IFN- $\gamma$, GM-CSF and IL-6 (Fig. 5). Except for IL-6, all of these cytokines were specifically detected only in co-cultures of UniCAR T-cells with $\mathrm{STn}^{+}$cancer cells in the presence of $\alpha \mathrm{STn}$ or $\alpha \mathrm{STn}$ IgG4 TMs, with a significantly higher amount of secreted cytokines for the $\alpha \mathrm{STn}$-IgG4 TM in comparison to the $\alpha$ STn TM. Nevertheless, IL- 6 was detected in all a

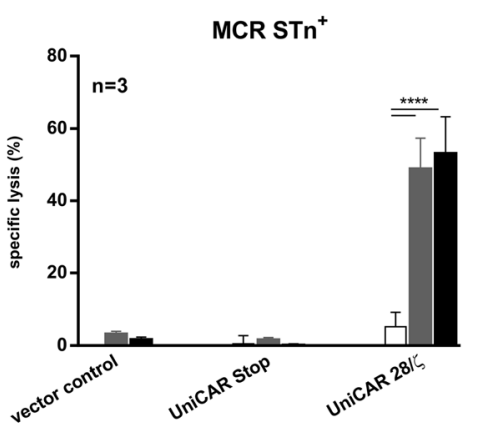

C

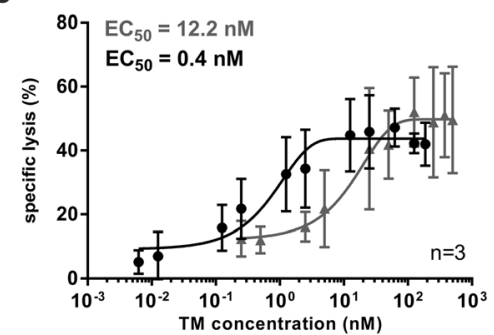

b

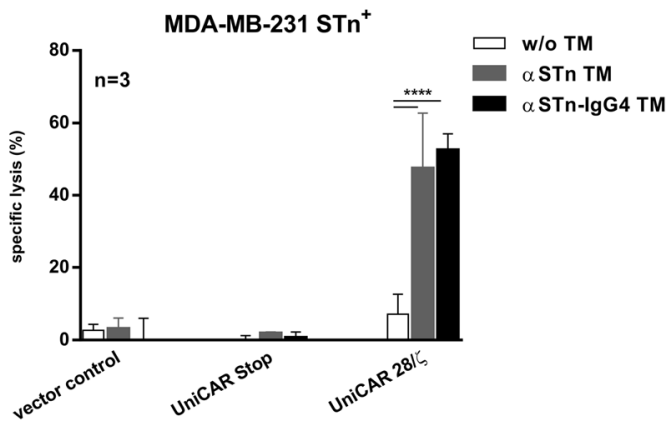

d

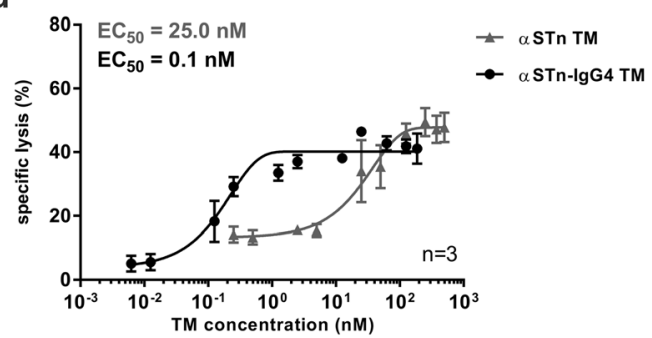

Fig. 4 Cytotoxic potential of retargeted UniCAR T-cells via aSTn-IgG4 TM. Killing of MDA-MB-231 STn ${ }^{+}$(b) and MCR STn ${ }^{+}$(a), was determined using standard chromium release assay. Chromium-labeled STn-expressing cell lines were incubated with control T-cells (vector control and UniCAR Stop) or UniCAR 28/Z T-cells for $24 \mathrm{~h}$ at an E:T ratio of 5:1, in the presence or absence of 10 pmol aSTn TM and aSTn-lgG4 TM. $\mathbf{c}$ and $\mathbf{d}$ Following a similar experimental setup using increasing TM concentrations, half maximal effective concentration ( $E_{50}$ ) was determined from the resulting dose-response curves using MDA-MB-231 STn ${ }^{+}$(c) and $\mathrm{MCR} \mathrm{STn}^{+}$(d) cells. Data for three individual donors were summarized as mean specific lysis \pm SD. Statistical significance was obtained using 2-way ANOVA with Bonferroni multiple-comparison test ${ }^{* * * *} p<0.0001$, with respect to w/o TM experimental setting) 


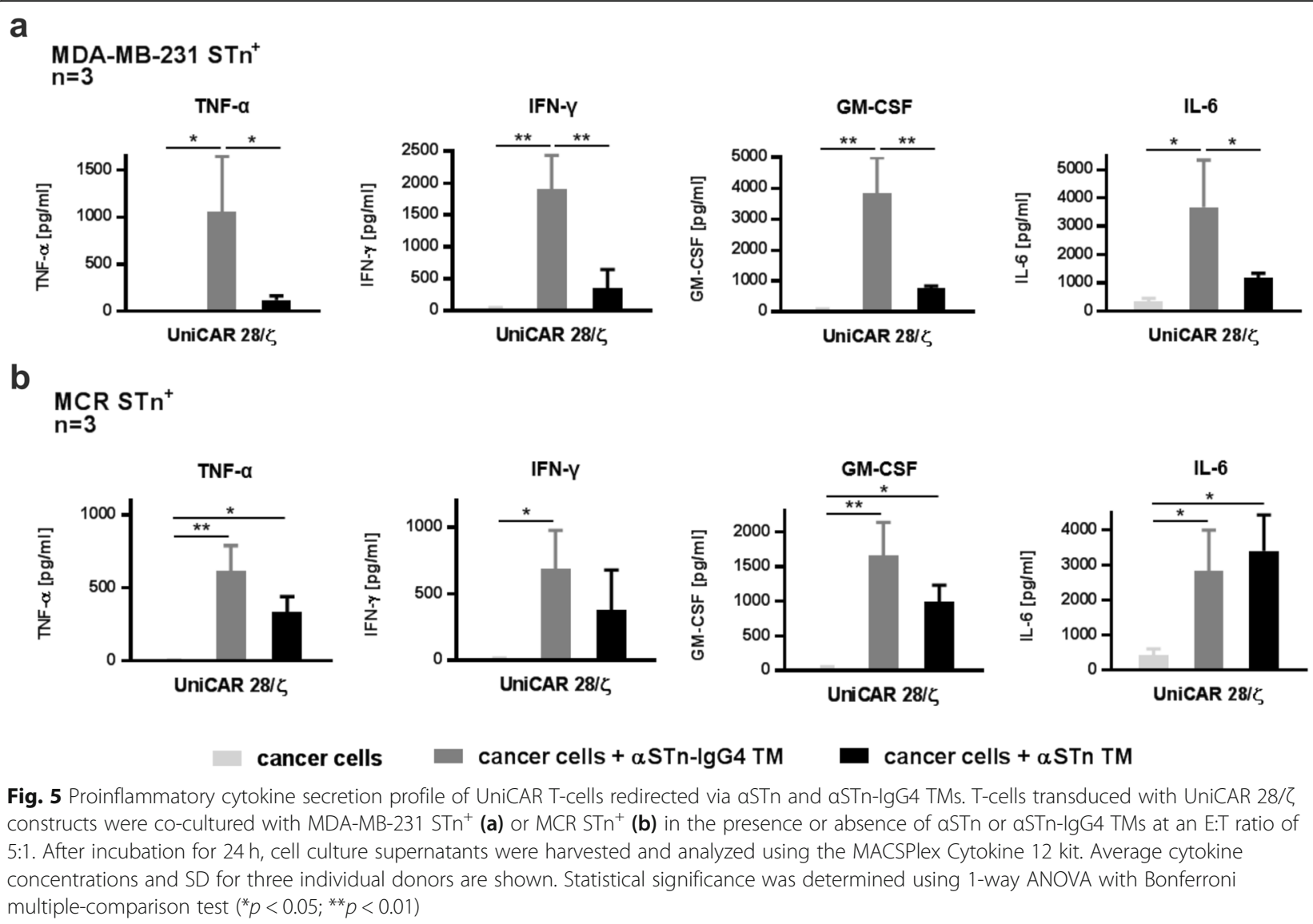

conditions that include cancer cells, suggesting that IL-6 is intrinsically secreted by the STn-expressing cancer cell lines used. This is in accordance with similar results previously observed for the $\alpha \mathrm{STn}$ TM using the same cell lines [12]. Importantly, none of the tested cytokines were present in supernatants recovered from negative control UniCAR T-cells (UniCAR Stop and vector control) or from UniCAR T-cells in the absence of TM and cancer cells (Fig. S2). Overall, the release of proinflammatory cytokines was specifically observed for the combination of UniCAR T-cells in the presence of target cancer cells and $\alpha$ STn-IgG4 TM.

Efficient and TM-dependent inhibition of tumor growth in experimental mice by UniCAR T-cells redirected with the aSTn-IgG4 TM

Once killing efficiency was validated in vitro, the in vivo anti-tumor activity of UniCAR T-cells retargeted via the $\alpha$ STn-IgG4 TM was analyzed using a xenograft tumor mouse model. For that, MDA-MB-231 STn ${ }^{+}$cells transduced with luciferase (MDA-MB-231 STn ${ }^{+}$Luc cells) were required to allow tumor imaging and follow-up during the experiment. Consequently, five groups of NOD-SCID mice were created. Three groups were injected subcutaneously with MDA-MB-231 STn ${ }^{+} \mathrm{Luc}$ cells alone, MDA-MB-231 $\mathrm{STn}^{+}$Luc cells with $\alpha \mathrm{STn}$ IgG4 TM or MDA-MB-231 STn ${ }^{+}$Luc cells with UniCAR T-cells, serving as controls. For the two treatment groups, MDA-MB-231 STn ${ }^{+}$Luc cells with UniCAR Tcells and $\alpha$ STn TM or $\alpha$ STn-IgG4 TM were injected. Tumor growth was monitored over 3 days by bioluminescence imaging. Qualitative imaging and corresponding quantitative results are shown in Fig. 6a and b, respectively. Corroborating the in vitro data, injection of $\mathrm{STn}^{+}$ target cells with UniCAR $28 / \zeta$ T-cells and $\alpha$ STn or $\alpha$ STn-IgG4 TMs significantly inhibited tumor growth already 1 day after injection. Absence of tumors was further verified up to 3 days after injection. Conversely and as expected for the control groups, injection of UniCAR T-cells or $\alpha S T n$-IgG4 TM alone did not hinder tumor growth. The quantitative analysis of the imaging results reveals an increased killing potential of $\alpha \mathrm{STn}$-IgG4redirected UniCAR T-cells compared to the $\alpha S T n T M$, represented by a more pronounced decrease in tumor bioluminescence intensity obtained upon injection of the $\alpha$ STn-IgG4 TM (Fig. 6b). These results demonstrate the effective and TM-dependent eradication of STnexpressing tumors by redirected UniCAR T-cells in vivo, with significant inhibition of tumor growth using the aSTn-IgG4 TM. 


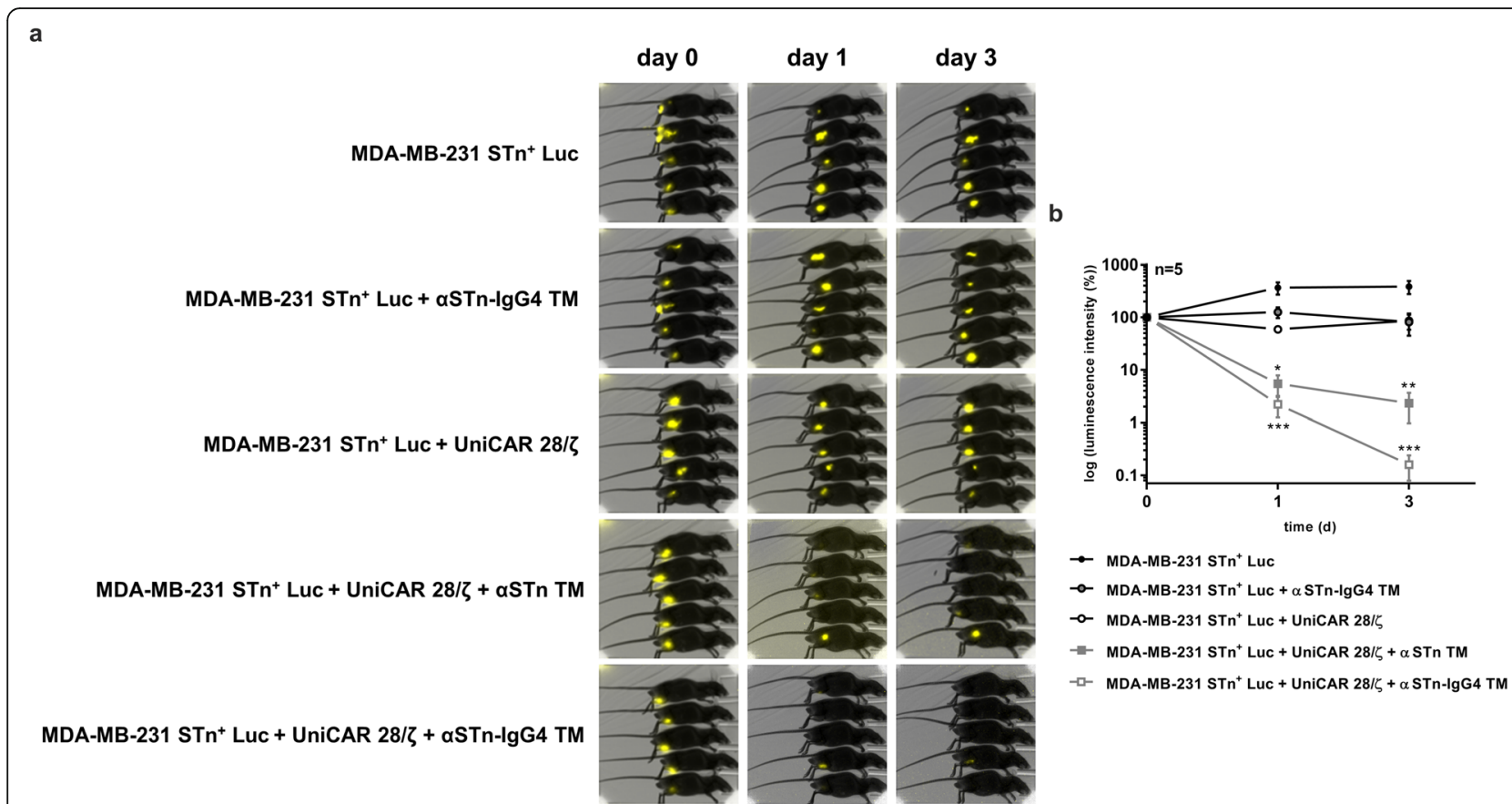

Fig. 6 In vivo killing capacity of redirected UniCAR T-cells in NOD-SCID mice using aSTn-lgG4 and aSTn TMs. Five groups composed of five NODSCID mice were established, from which mice injected with MDA-MB-231 STn ${ }^{+}$Luc tumor cells alone; tumor cells mixed with aSTn-lgG4 TM or

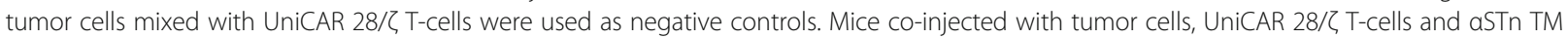
or aSTn-IgG4 TM were used as treatment groups. All injections were performed subcutaneously into the right hind flank. a Bioluminescence imaging of anesthetized mice was performed at day 0,1 and 3. b Based on the luminescence imaging results obtained, a quantitative analysis was performed. The values were normalized to the initial measurement performed after injection on day 0 and represented as mean \pm SEM. Statistical significance was determined using two-way ANOVA with Bonferroni multiple-comparison test with respect to the control group injected with MDA-MB-231 STn ${ }^{+}$Luc and UniCAR 28/ל T-cells $\left({ }^{*} p<0.1 ;{ }^{* *} p<0.01 ;{ }^{* *} p<0.001\right.$ )

\section{Kinetics and PET imaging of the aSTn-IgG4 TM in mice bearing $\mathrm{STn}^{+}$tumors}

To evaluate the pharmacokinetics of the radiolabeled aSTn-IgG4 TM for in vivo imaging of STnoverexpressing tumor sites, the $\alpha \mathrm{STn}$-IgG4 TM was conjugated with the chelator NODAGA and further labeled with the PET isotope copper resulting in $\left[{ }^{64} \mathrm{Cu}\right] \mathrm{Cu}$ NODAGA- $\alpha$ STn-IgG4 TM. A labeling yield and radiochemical purity (decay-corrected) of $94 \pm 5 \%$ was determined by radio-ITLC. Furthermore, a molar activity of $11 \pm 8 \mathrm{GBq} / \mu \mathrm{mol}$ was obtained. For comparison, the $\alpha S T n$ TM was conjugated with NODAGA and labeled with copper following a similar protocol. To perform small animal PET, MDA-MB-231 STn ${ }^{+}$Luc tumors were established on the right shoulder of NOD-SCID mice 2 weeks prior to injection of the radiolabeled TMs. Figure $7 \mathrm{a}$ summarizes accumulation at the tumor site and clearance of the $\left[{ }^{64} \mathrm{Cu}\right] \mathrm{Cu}-\mathrm{NODAGA}-\alpha \mathrm{STn}-\mathrm{IgG} 4 \mathrm{TM}$ over 3 days. As shown, a maximum accumulation at the tumor site was observed around $46 \mathrm{~h}$ after injection with a slow blood clearance between 50 to $66 \mathrm{~h}$ (Fig. $7 \mathrm{a}$ and b). These data indicate that the $\alpha \mathrm{STn}$-IgG4 TM has a delayed maximum accumulation at the tumor compared to the $\alpha \mathrm{STn}$ scFv-based TM (around $2 \mathrm{~h}$ ). Additionally, a longer lasting accumulation is obtained in contrast to the scFv-based TM. Furthermore, time activity curves of the dynamic PET analysis of blood were used to determine serum half-life (Fig. 7c). Based on the values of the area-under-curve obtained for the $\left[{ }^{64} \mathrm{Cu}\right] \mathrm{Cu}$-NODAGA$\alpha$ STn TM and $\left[{ }^{64} \mathrm{Cu}\right] \mathrm{Cu}-\mathrm{NODAGA}-\alpha \mathrm{STn}-\mathrm{IgG} 4 \mathrm{TM}$ (40.3 and 200.2, respectively), blood half-life values of $1.2 \mathrm{~h}$ for the $\alpha \mathrm{STn}$ TM and $12 \mathrm{~h}$ for the $\alpha \mathrm{STn}-\mathrm{IgG} 4 \mathrm{TM}$ were calculated. In summary, the obtained results demonstrate a specific and long-lasting accumulation of the $\alpha S T n-I g G 4$ TM at the tumor site in accordance with its extended half-life.

\section{Discussion}

Recently, switchable adapter CAR T-cell platforms have been established to circumvent the main hurdles of conventional CAR T-cell therapies [5]. Thereby, activity of CAR T-cells is controlled based on the specificity, size, molecular design and pharmacokinetics of the selected CAR adaptor. Our group established the modular UniCAR platform, in which various TMs with short half-life targeting different tumor-associated antigens have been demonstrated to redirect UniCAR T-cells to specifically eradicate tumor cells [8-12]. As a key 
a

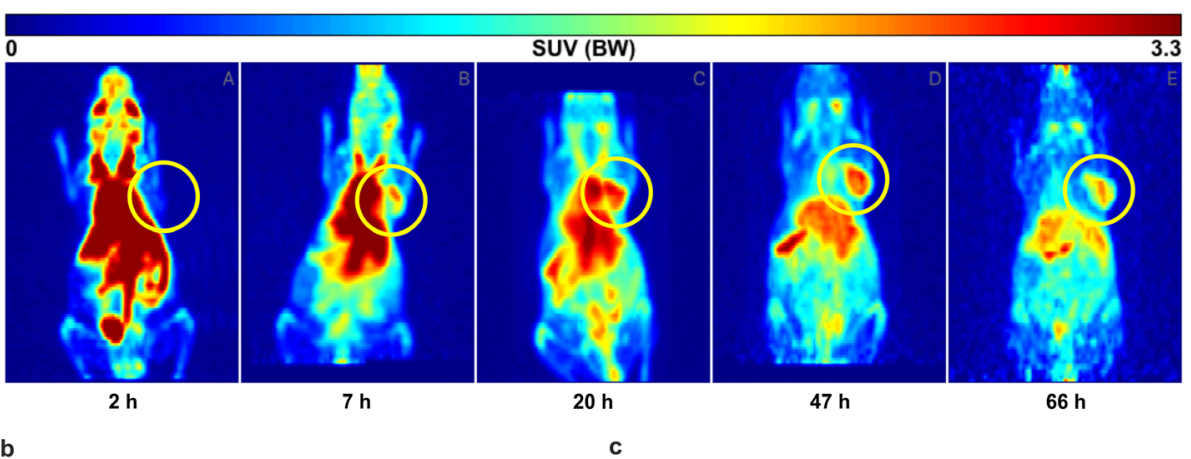

b

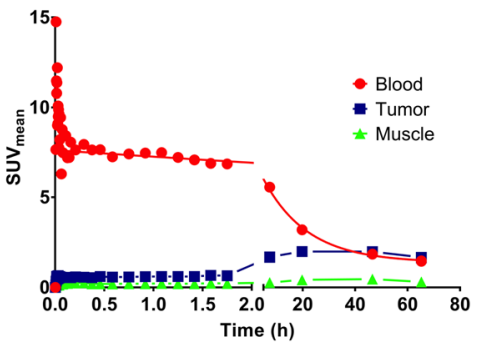

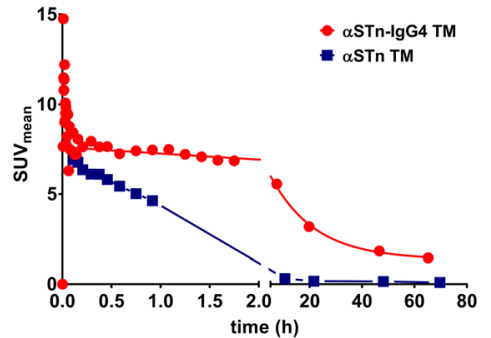

Fig. 7 PET analysis of STn ${ }^{+}$tumor-bearing mouse injected with $\left[{ }^{64} \mathrm{Cu}\right] \mathrm{Cu}-\mathrm{NODAGA-aSTn}-\mathrm{lgG} 4 \mathrm{TM}$. The TMs were conjugated with NODAGA, labeled with copper-64 $\left({ }^{64} \mathrm{Cu}\right)$ and injected as a single bolus intravenously into NOD-SCID mice bearing established MDA-MB-231 STn ${ }^{+}$LuC tumors. a Representative coronal view of the maximum intensity projection (MIP) of the $\left[{ }^{64} \mathrm{Cu}\right] \mathrm{Cu}-\mathrm{NODAGA}-a \mathrm{STn}$-IgG4 TM distribution after 2, 7, 20, 47 and $66 \mathrm{~h}$. Tumor is highlighted by yellow circles. b Time activity curves (TAC) of the dynamic PET analysis of regions of interest (ROI) obtained using the radiolabeled aSTn-lgG4 TM for blood, tumor and muscle. c Comparative view of blood TAC for the aSTn-lgG4 (red curve) and aSTn TMs (blue curve) over 66 h. SUV, standard uptake values

prerequisite of the UniCAR system, TMs should be rapidly eliminated from the peripheral blood to provide a quick steering and self-limiting safety switch in case severe side effects arise. Consequently, activation and potential adverse effects of UniCAR T-cells can be easily tuned by dosing TM infusions. To overcome the continuous infusion required for such small-sized TMs at later stages of therapy, we developed an extended halflife TM targeting the STn antigen based on the backbone of human IgG4 antibodies. For that, the scFv derived from the mAb L2A5 and the E5B9 epitope were fused to the human IgG4 hinge and Fc region. The backbone of the IgG4 molecule was chosen due to the limited binding to Fc receptors as well as the weak or absent activation of both complement and antibodydependent cellular cytotoxicity [29]. As a result, IgG4 antibodies have been widely used to design therapeutic antibodies when a weak or absent immune cell activation is desired, yet maintaining an increased plasmatic half-life comparable to the other IgG subclasses [30].

We successfully produced a homodimeric $\alpha \mathrm{STn}$-IgG4 TM with considerably high purity that specifically binds to STn-expressing cancer cell lines and promotes efficient tumor cell lysis by redirected UniCAR T-cells both in vitro and in experimental mice. Both scFv-based and IgG4-based TMs bind to $\mathrm{STn}^{+}$cancer cells with high affinity. Bearing in mind that the underlying anti-STn
mAb L2A5 is a dekavalent IgM mAb [28], the high calculated affinities of these TMs were surprising. Comparing both TMs, a 12 to 17 -fold increase in binding affinity was obtained for the $\alpha \mathrm{STn}$-IgG4 TM ( $4 \mathrm{nM}$ compared to $57 \mathrm{nM}$ and $75 \mathrm{nM}$ ). This result can be mainly explained by the fact that the $\alpha \mathrm{STn}-\mathrm{IgG} 4 \mathrm{TM}$ has two binding sites in contrast to the monovalent $\alpha \mathrm{STn}$ TM. Furthermore, lower amounts of IgG4-based TM were required to obtain similar specific cell lysis compared to the scFv-based TM. This may again be explained due to the geometry and valency of the $\alpha \mathrm{STn}$-IgG4 TM. Emphasis should also be placed to the importance of the distance and molecular geometry of the immunological synapse to ensure adequate activation of effector cell functions. Previous studies using conventional CARs have reported attenuated activation signaling due to the formation of longer immunological synapses and variations in the antigen location and density on target cells [31, 32]. Interestingly, recent reports highlight the effective formation of the immunological synapse and consequent $\mathrm{T}$ cell activation using different modular CAR formats, demonstrating a surprising plasticity and variability of such approaches [3, 33, 34]. Here, we demonstrate that the immunological synapse formed by the large $\alpha$ STn-IgG4 TMs does not affect the activation nor cytotoxic potential of UniCAR T-cells targeting the STn antigen. This validates the versatility of the UniCAR 
system, which can be easily combined with TM formats of different sizes and designs without hampering UniCAR T-cell activation and killing efficiency. Accordingly, upon TM-mediated cancer cell lysis, UniCAR T-cells secreted the cytokines TNF- $\alpha$, IFN- $\gamma$, GM-CSF and IL-2. Worth mentioning, IL-6, which is mainly held responsible for cytokine release syndrome, was detected in supernatants of samples containing target cells regardless of the presence or absence of the $\alpha \mathrm{STn}$-IgG4 TM. This suggests that IL-6 is released by MDA-MB-231 and MCR cancer cells and not by activated UniCAR T-cells, which is in line with our previous publication and other studies [12, 35, 36]. As stated before, proinflammatory cytokines are specifically released following TMdependent cross-linkage of tumor and UniCAR T-cells. TNF- $\alpha$, IFN- $\gamma$ and GM-CSF are known to be involved in mechanisms such as induction of tumor cell apoptosis as well as proliferation and activation of T-cells. The aforementioned cytokines can further stimulate other immune cells to overcome the immunosuppressive microenvironment often seen in solid cancers, including $\mathrm{STn}^{+}$tumors [37]. Moreover, STn has been recently reported to be expressed on the surface of infiltrating myeloid derived suppressor cells (MDSCs) [37]. Hence, in a clinical setting eradication of STn-expressing tumors via redirected UniCAR T-cells may be augmented by the additional depletion of immune-suppressive MDSCs, which subsequently endorses immune re-engagement.

PET imaging results show a specific enrichment of the $\alpha S T n-I g G 4$ TM at the tumor site with maximum accumulation at around $46 \mathrm{~h}$ after injection and a slow clearance between 50 to $66 \mathrm{~h}$. Furthermore, dynamic PET analysis emphasizes the extended blood half-life of $12 \mathrm{~h}$ for the $\alpha$ STn-IgG4 TM compared to approximately $1 \mathrm{~h}$ obtained for the $\alpha \mathrm{STn}$ TM. These properties of the $\alpha S T n$-IgG4 TM are mainly related to its increased molecular weight, which leads to a delayed but prolonged accumulation at the tumor, additionally preventing its rapid clearance via the kidneys. FcRn-mediated recycling may also play a role and affect the lifespan of the $\alpha \mathrm{STn}$ IgG4 TM, increasing the retention time of this molecule in the plasma [38]. In light of future clinical applications, combination of small-sized and extended half-life TMs with UniCAR T-cells might allow a more convenient treatment regimen for cancer patients. During onset of therapy when tumor burden is high, an scFv-based TM should be continuously applied to enable a rapid offswitch of UniCAR T-cells by ceasing TM infusion in case of unwanted toxicities. In later stages of therapy, when tumor burden is lower and thus side effects are less likely to occur, the use of a TM with extended halflife may be important to reduce the number of infusions as well as to enhance eradication of residual tumor cells. Such an approach may be particularly relevant when targeting STn-expressing tumors, as STn expression is frequently associated with tumor invasiveness, metastasis and immune escape, especially in breast and bladder cancer [17, 39-41]. Even though the blood clearance of the IgG4-based TM is considerably delayed, the safety profile is not compromised since the TM would be eliminated at some point and therefore, a controlled inactivation of UniCAR T-cells would be achieved. In this way, the risk to develop long-term side effects caused by continuously activated conventional CAR T-cells would still be minimized.

The pharmacokinetic features and stable accumulation of radiolabeled $\alpha \mathrm{STn}$-IgG4 TMs at the tumor site combined with the possibility to simultaneously redirect UniCAR T-cells to eradicate tumor cells further highlights its potential application for theranostic purposes. Thus, therapy and tumor imaging could be combined in a single radiolabeled TM aiming at a patient-centered care. Depending on the selected radionuclide, the modified TM might be routinely used for PET/CT imaging or endoradiotherapy. In that way, the radiolabeled $\alpha \mathrm{STn}$ IgG4 TM could be used as a tracer for diagnosis and monitoring of tumor diseases while enabling simultaneous immunotherapy with the UniCAR system. Yet, additional work and validation are required in this regard.

\section{Conclusions}

Taken together, a novel IgG4-based TM with extended half-life targeting the STn antigen has been developed and proven to efficiently redirect UniCAR T-cells to STn-expressing cancer cells in a highly target-specific manner both in vitro and in vivo. Thereby, the UniCAR T-cell technology can be used in a customized way, in which TMs with different pharmacokinetic features, and if required with different specificities, can be administered according to the stage and demands observed during cancer therapy. Contrarily to the current conventional CAR T-cell therapies, this type of tailored approach would provide a more convenient and controllable way to treat patients according to the therapy stage and response to treatment. Furthermore, radiolabeled TMs may be attractive candidates for diagnostics and therapy monitoring. Their high potential for theranostic applications fosters the transition from conventional to personalized medicine.

\section{Supplementary information}

Supplementary information accompanies this paper at https://doi.org/10. 1186/s13046-020-01572-4.

Additional file 1: Figure S1. Binding of aSTn and aSTn-lgG4 TMs to MDA-MB-231 and MCR wild-type (WT) cancer cells. Both MDA-MB-231 and MCR WT cancer cells were stained with $1 \mu \mathrm{g}$ of TMs, mAb $5 B 9$ and PE-labeled anti-mouse-lgG mAb. The aSTn L2A5 mAb was detected using an Alexa Fluor 488 anti-mouse IgM mAb. Stained cells (black lines) and 
respective isotype controls (grey lines) are displayed as histograms. MFI values are shown. Results for one representative binding assay are shown. Figure S2. Cross-linkage of UniCAR T-cells with $\mathrm{STn}^{+}$tumor cells via aSTn-IgG4 TM results in release of cytokines. In a 24 h-cytokine-release assay, (a) MDA-MB-231 STn ${ }^{+}$or (b) MCR STn ${ }^{+}$cells were incubated with vector control, UniCAR Stop or UniCAR 28/乙 T-cells in the presence or absence of aSTn-IgG4 TM (E:T ratio of 5:1). Cytokine concentrations in cellfree co-culture supernatants were detected using the MACSPlex Cytokine 12 kit. Average cytokine concentrations and SD for three individual donors are shown. Statistical significance was determined using 2-way ANOVA with Bonferroni multiple-comparison test $\left({ }^{* *} p<0.01 ;{ }^{* *} p<0.001\right.$ and $\left.{ }^{* * *} p<0.0001\right)$.

\section{Abbreviations}

CAR: Chimeric antigen receptor; $\mathrm{C}_{\mathrm{H}} 2$ : Constant domain 2 of the heavy chain of a monoclonal antibody; $\mathrm{C}_{\mathrm{H}} 3$ : Constant domain 3 of the heavy chain of a monoclonal antibody; DMEM: Dulbecco's modified Eagle's medium; $\mathrm{EC}_{50}$ : Half maximal effective concentration; EDTA: Ethylenediamine tetraacetic acid; EGFP: Enhanced green fluorescent protein; ELISA: Enzyme-linked immunosorbent assay; E:T: Effector to target cells; FBS: Fetal bovine serum; IgG4: Immunoglobulin 4; $K_{D}$ : Equilibrium dissociation constant; Luc: Firefly luciferase; mAb: monoclonal antibody; MDSCs: Myeloid derived suppressor cells; MFI: Median fluorescence intensities; MW: Molecular weight; NODSCID: Non-obese diabetic-severe combined immune-deficient; PBMCs: Peripheral blood mononuclear cells; PBS: Phosphate buffered saline; PET: Positron emission tomography; CT: Computed tomography; radioITLC: radio thin-layer chromatography; scFv: single-chain variable fragment; SD: Standard deviation; SDS-PAGE: Sodium dodecyl sulfate polyacrylamide gel electrophoresis; SE-HPLC: Size exclusion high-performance liquid chromatography; STn: Sialyl-Tn; SUV: Standard uptake values; TM: Target module; UniCAR: Universal CAR; $V_{H}$ : Variable domain of the heavy chain of a monoclonal antibody; $V_{L}:$ Variable domain of the light chain of a monoclonal antibody; WB: Western blot

\section{Acknowledgements}

We would like to thank Julia Lagler for the excellent technical assistance.

\section{Authors' contributions}

LRL established the TM, performed most of the experiments and analyzed the data. LRL and PAV established the anti-STn mAb L2A5. CA, RB and NB performed radiolabeling and imaging work. $M B$ is the inventor of the UniCAR system. AF, MB, DM, NH and KS provided critical reagents, know how and materials. LRL and CA conceived and designed the experiments. CA and MB supervised the study. LRL wrote the manuscript and AF, SK, MB and CA participated in review and revision. All authors read and approved the final manuscript.

\section{Funding}

Not applicable.

\section{Availability of data and materials}

Data confirming the results of this study are presented in the manuscript and are available from the corresponding author upon reasonable request.

\section{Ethics approval and consent to participate}

All animal procedures were conducted in accordance with the ARRIVE guidelines and the guidelines set by the European Communities Council Directive (86/609 EEC). The local Ethical Committee for Animal Experiments approved the animal facilities and the protocol according to institutional guidelines at the Semmelweis University approved by the Workplace Animal Ethical Committee (MÁB).

\section{Consent for publication}

Not applicable.

\section{Competing interests}

LRL, PAV and MB have filed patents related to anti-STn mAb L2A5. MBP has filed patents related to the UniCAR system. MB is shareholder of the company GEMoaB which owns the IP related to the UniCAR system. The other authors declare that they have no competing interests.

\section{Author details}

${ }^{1}$ Helmholtz-Zentrum Dresden-Rossendorf (HZDR), Institute of Radiopharmaceutical Cancer Research, Bautzner Landstrasse 400, 01328 Dresden, Germany. ${ }^{2}$ National Center for Tumor Diseases (NCT), Dresden, Germany; German Cancer Research Center (DKFZ), Heidelberg, Germany; Faculty of Medicine and University Hospital Carl Gustav Carus, Technische Universität Dresden, Dresden, Germany; Helmholtz-Zentrum

Dresden-Rossendorf (HZDR), Dresden, Germany. ${ }^{3}$ Department of Biophysics and Radiation Biology, Faculty of Medicine, Semmelweis University, Budapest, Hungary. ${ }^{4}$ UCIBIO, Departamento Ciências da Vida, Faculdade de Ciências e Tecnologia, Universidade NOVA de Lisboa, Caparica, Portugal. ${ }^{5}$ German Cancer Consortium (DKTK), partner site Dresden and German Cancer Research Center (DKFZ), Heidelberg, Germany. ${ }^{6}$ Tumor Immunology, University CancerCenter (UCC), University Hospital Carl Gustav Carus Dresden, Technische Universität Dresden, Dresden, Germany.

\section{Received: 4 February 2020 Accepted: 15 April 2020}

Published online: 05 May 2020

\section{References}

1. Sadelain M. CD19 CAR T cells. Cell. 2017;171:1471.

2. Urbanska K, Lanitis E, Poussin M, Lynn RC, Gavin BP, Kelderman S, et al. A universal strategy for adoptive immunotherapy of Cancer through use of a novel T-cell antigen receptor. Cancer Res. 2012;72:1844-52.

3. Tamada K, Geng D, Sakoda Y, Bansal N, Srivastava R, Li Z, et al. Redirecting gene-modified T cells toward various Cancer types using tagged antibodies. Clin Cancer Res. 2012;18:6436-45.

4. Cho JH, Collins JJ, Wong WW. Universal chimeric antigen receptors for multiplexed and logical control of T cell responses. Cell. 2018;173:14261438.e11.

5. Darowski D, Kobold S, Jost C, Klein C. Combining the best of two worlds: highly flexible chimeric antigen receptor adaptor molecules (CAR-adaptors) for the recruitment of chimeric antigen receptor $\mathrm{T}$ cells. MAbs. 2019;11:621-31.

6. Bachmann M. The UniCAR system: a modular CAR T cell approach to improve the safety of CAR T cells. Immunol Lett. 2019;211:13-22.

7. Koristka S, Cartellieri M, Feldmann A, Arndt C, Loff S, Michalk I, et al. Flexible antigen-specific redirection of human regulatory $T$ cells via a novel universal chimeric antigen receptor system. Blood. 2014;124:3494.

8. Cartellieri M, Feldmann A, Koristka S, Arndt C, Loff S, Ehninger A, et al. Switching CAR T cells on and off: a novel modular platform for retargeting of T cells to AML blasts. Blood Cancer J. 2016;6:e458.

9. Feldmann A, Arndt C, Bergmann R, Loff S, Cartellieri M, Bachmann D, et al. Retargeting of T lymphocytes to PSCA- or PSMA positive prostate cancer cells using the novel modular chimeric antigen receptor platform technology "UniCAR". Oncotarget. 2017;8:31368-85.

10. Albert S, Arndt C, Feldmann A, Bergmann R, Bachmann D, Koristka S, et al. A novel nanobody-based target module for retargeting of T lymphocytes to EGFR-expressing cancer cells via the modular UniCAR platform. Oncoimmunology. 2017;6:e1287246.

11. Mitwasi N, Feldmann A, Bergmann R, Berndt N, Arndt C, Koristka S, et al. Development of novel target modules for retargeting of UniCAR T cells to GD2 positive tumor cells. Oncotarget. 2017;8:108584-603.

12. Loureiro LR, Feldmann A, Bergmann R, Koristka S, Berndt N, Arndt $C$, et al. Development of a novel target module redirecting UniCAR T cells to Sialyl Tn-expressing tumor cells. Blood Cancer J. 2018;8:81.

13. Victorzon M, Nordling S, Nilsson O, Roberts PJ, Haglund C. Sialyl Tn antigen is an independent predictor of outcome in patients with gastric cancer. Int J Cancer. 1996;65:295-300.

14. Itzkowitz SH, Bloom EJ, Kokal WA, Modin G, Hakomori S, Kim YS. Sialosyl-Tn. A novel mucin antigen associated with prognosis in colorectal cancer patients. Cancer. 1990;66:1960-6.

15. Kobayashi H, Terao T, Kawashima Y. Serum sialyl Tn as an independent predictor of poor prognosis in patients with epithelial ovarian cancer. J Clin Oncol. 1992;10:95-101.

16. Leivonen M, Nordling S, Lundin J, von Boguslawski K, Haglund C. STn and prognosis in breast cancer. Oncology. 2001;61:299-305.

17. Ferreira JA, Videira PA, Lima L, Pereira S, Silva M, Carrascal M, et al. Overexpression of tumour-associated carbohydrate antigen sialyl-Tn in advanced bladder tumours. Mol Oncol. 2013;7:719-31. 
18. Julien S, Adriaenssens E, Ottenberg K, Furlan A, Courtand G, VercoutterEdouart AS, et al. ST6GalNAc I expression in MDA-MB-231 breast cancer cells greatly modifies their O-glycosylation pattern and enhances their tumourigenicity. Glycobiology. 2006;16:54-64.

19. Pinho S, Marcos NT, Ferreira B, Carvalho AS, Oliveira MJ, Santos-Silva F, et al. Biological significance of cancer-associated sialyl-Tn antigen: modulation of malignant phenotype in gastric carcinoma cells. Cancer Lett. 2007;249:157-70.

20. Munkley J. The role of sialyl-Tn in cancer. Int J Mol Sci. 2016;17:275.

21. Julien S, Krzewinski-Recchi MA, Harduin-Lepers A, Gouyer V, Huet G, Le Bourhis $X$, et al. Expression of Sialyl-Tn antigen in breast cancer cells transfected with the human CMP-Neu5Ac: GalNAc a2,6-sialyltransferase (ST6GalNAc I) cDNA. Glycoconj J. 2001;18:883-93.

22. Arndt C, Feldmann A, von Bonin M, Cartellieri M, Ewen E, Koristka S, et al. Costimulation improves the killing capability of $T$ cells redirected to tumor cells expressing low levels of CD33 : description of a novel modular targeting system. Leukemia. 2014;28:59-69.

23. Feldmann A, Arndt C, Topfer K, Stamova S, Krone F, Cartellieri M, et al. Novel humanized and highly efficient Bispecific antibodies mediate killing of prostate stem cell antigen-expressing tumor cells by CD8+ and CD4+ T cells. J Immunol. 2012;189:3249-59.

24. Arndt C, Feldmann A, Koristka S, Cartellieri M, Dimmel M, Ehninger A, et al. Simultaneous targeting of prostate stem cell antigen and prostate-specific membrane antigen improves the killing of prostate cancer cells using a novel modular T cell-retargeting system. Prostate. 2014;74:1335-46.

25. Cartellieri M, Koristka S, Arndt C, Feldmann A, Stamova S, von Bonin M, et al. A novel ex vivo isolation and expansion procedure for chimeric antigen receptor engrafted human T cells. PLoS One. 2014;9:e93745.

26. Feldmann A, Stamova S, Bippes CC, Bartsch H, Wehner R, Schmitz M, et al. Retargeting of $T$ cells to prostate stem cell antigen expressing tumor cells: comparison of different antibody formats. Prostate. 2011;71:998-1011.

27. David T, Hlinová V, Kubíček V, Bergmann R, Striese F, Berndt N, et al. Improved conjugation, 64-cu radiolabeling, in vivo stability, and imaging using nonprotected Bifunctional macrocyclic ligands: Bis (Phosphinate) Cyclam (BPC) Chelators. J Med Chem. 2018;61:8774-96.

28. Loureiro LR, Sousa DP, Ferreira D, Chai W, Lima L, Pereira C, et al. Novel monoclonal antibody L2A5 specifically targeting sialyl-Tn and short glycans terminated by alpha-2-6 sialic acids. Sci Rep. 2018;8:12196.

29. Johnson DE. Biotherapeutics: challenges and opportunities for predictive toxicology of monoclonal antibodies. Int J Mol Sci. 2018;19:3685.

30. Dumet C, Pottier J, Gouilleux-Gruart V, Watier H. Insights into the IgG heavy chain engineering patent landscape as applied to IgG4 antibody development. MAbs. 2019;11:1-10.

31. Kulemzin SV, Kuznetsova W, Mamonkin M, Taranin AV, Gorchakov AA. Engineering chimeric antigen receptors. Acta Nat. 2017;9:6-14.

32. Rodgers DT, Mazagova M, Hampton EN, Cao Y, Ramadoss NS, Hardy IR, et al. Switch-mediated activation and retargeting of CAR-T cells for B-cell malignancies. Proc Natl Acad Sci U S A. 2016;113:E459-68.

33. Ochi F, Fujiwara H, Tanimoto K, Asai H, Miyazaki Y, Okamoto S, et al. Genemodified human a/ $\beta-T$ cells expressing a chimeric CD16-CD3 3 receptor as adoptively transferable effector cells for anticancer monoclonal antibody therapy. Cancer Immunol Res. 2014;2:249-62.

34. Tanaka H, Fujiwara H, Ochi F, Tanimoto K, Casey N, Okamoto S, et al. Development of engineered T cells expressing a chimeric CD16-CD3 receptor to improve the clinical efficacy of Mogamulizumab therapy against adult T-cell leukemia. Clin Cancer Res. 2016;22:4405-16.

35. Casneuf T, Axel AE, King P, Alvarez JD, Werbeck JL, Verhulst T, et al. Interleukin-6 is a potential therapeutic target in interleukin-6 dependent, estrogen receptor-a-positive breast cancer. Breast Cancer. 2016;8:13-27.

36. Severino PF, Silva M, Carrascal M, Malagolini N, Chiricolo M, Venturi G, et al. Expression of sialyl-Tn sugar antigen in bladder cancer cells affects response to Bacillus Calmette Guérin (BCG) and to oxidative damage. Oncotarget. 2017:8:54506-17.

37. Eavarone DA, Rao PE, Prendergast JM, Curtis AD, Zhang R, Shopland LS, et al. Abstract 5625: myeloid derived suppressor cells (MDSCs) express Sialyl Tn (STn) and are a therapeutic target for anti-STn antibody drug conjugates. Clin Res. 2018;78:615

38. Pyzik M, Rath T, Lencer WI, Baker K, Blumberg RS. FcRn: the architect behind the immune and nonimmune functions of IgG and albumin. J Immunol. 2015;194:4595-603.

39. Soares R, Marinho A, Schmitt F. Expression of sialyl-Tn in breast cancer: correlation with prognostic parameters. Pathol Res Pract. 1996;192:1181-6.
40. Schultz MJ, Swindall AF, Bellis SL. Regulation of the metastatic cell phenotype by sialylated glycans. Cancer Metastasis Rev. 2012;31:501-18.

41. Carrascal MA, Severino PF, Guadalupe Cabral M, Silva M, Ferreira JA, Calais F. Sialyl Tn-expressing bladder cancer cells induce a tolerogenic phenotype in innate and adaptive immune cells. Mol Oncol. 2014;8:753-65.

\section{Publisher's Note}

Springer Nature remains neutral with regard to jurisdictional claims in published maps and institutional affiliations.
Ready to submit your research? Choose BMC and benefit from:

- fast, convenient online submission

- thorough peer review by experienced researchers in your field

- rapid publication on acceptance

- support for research data, including large and complex data types

- gold Open Access which fosters wider collaboration and increased citations

- maximum visibility for your research: over $100 \mathrm{M}$ website views per year

At $\mathrm{BMC}$, research is always in progress.

Learn more biomedcentral.com/submissions 